\title{
Chest Physical Therapy in Acute Viral Bronchiolitis: An Updated Review
}

\author{
Guy Postiaux PT, Bruno Zwaenepoel PT, and Jacques Louis MD \\ Introduction \\ Physiopathology of Acute Viral Bronchiolitis \\ Treatments in Acute Viral Bronchiolitis \\ Medications \\ Chest Physical Therapy \\ Summary
}

\begin{abstract}
We describe the various therapies for infant acute viral bronchiolitis and the contradictory results obtained with chest physical therapy. The treatment target is bronchial obstruction, which is a multifactorial phenomenon that includes edema, bronchoconstriction, and increased mucus production, with a clinical grading defined as severe, moderate, or mild. Chest physical therapy is revisited in its various modalities, according to preliminary scoring of the disease. Key words: infant acute viral bronchiolitis; bronchial obstruction; chest physical therapy; airway mucus clearance. [Respir Care 2013;58(9):1541-1545. (C) 2013 Daedalus Enterprises]
\end{abstract}

\section{Introduction}

Acute viral bronchiolitis is the most common disorder and the leading cause of respiratory failure in infants $(<24$ months of age). Respiratory syncytial virus is the

\footnotetext{
Mr Postiaux and Dr Louis are affiliated with the Department of Pediatrics, Grand Hôpital de Charleroi, Charleroi, Belgium. Mr Zwaenepoel is affiliated with Rehabilitation Sciences and Physiotherapy, Ghent University, Ghent, Belgium.

The authors have disclosed no conflicts of interest.

Guy Postiaux presented a version of this paper at the meeting of the Associação Brasileira de Fisioterapia Cardiorrespiratória e Fisioterapia em Terapia Intensiva (ASSOBRAFIR), held May 16, 2012, in Rio de Janeiro, Brazil.
}

Supplementary material related to this paper is available at http:// www.rcjournal.com.

Correspondence: Guy Postiaux PT, Site Reine Fabiola, Avenue du Centenaire 73, 6061 Montignies-sur-Sambre, Charleroi, Belgium. E-mail: guy.postiaux@gmail.com.

DOI: $10.4187 /$ respcare. 01890 most common pathogen $(85 \%)$, but other organisms produce a similar clinical picture. ${ }^{1}$ The disease can be graded as severe, moderate, or mild, and for each presentation a score is applied, as proposed by Wang. ${ }^{2}$ The Wang clinical severity score is now prevailing in evaluating the treatment with hypertonic saline nebulization or chest physical therapy (CPT). The Wang clinical severity score has a good inter-observer agreement among caregivers, which is reinforcing its value. ${ }^{3-6}$

Severe bronchiolitis is characterized by retraction as well as inspiratory and expiratory wheezing, with a breathing frequency exceeding 60 breaths/min, and $\mathrm{S}_{\mathrm{pO}_{2}}<90 \%$. Nasal flaring, somnolence, and apnea can also be present; feeding is impossible. Hospitalization is required; minimal handling is the rule, and oxygen is needed, as well as intravenous hydration and, in some cases, mechanical ventilation. Currently, its treatment is supportive care. ${ }^{7}$ Noninvasive ventilation can be used as primary ventilatory support, or CPAP, used either alone or with heliox..$^{8-10}$ In severe bronchiolitis the Wang clinical severity score ranges from 9 to 12 .

In moderate bronchiolitis the breathing frequency ranges from 40 to 60 breaths/min, and $\mathrm{S}_{\mathrm{pO}_{2}}$ from $90 \%$ to $93 \%$. 


\section{Chest Physical Therapy in Acute Viral Bronchiolitis}

Wheezing is mainly expiratory, with intercostal retraction and poor feeding ability. Supplemental oxygen and fluids per os are the mainstay of therapy. In moderate bronchiolitis the Wang clinical severity score ranges from 4 to 8 .

In mild bronchiolitis the breathing frequency is $<40$ breaths/min, with $\mathrm{S}_{\mathrm{pO}_{2}} \geq 94 \%$, end-expiratory wheezing, and absent or minimal retraction. Feeding is normal. Wang clinical severity score does not exceed 3 . This is the most frequent presentation of bronchiolitis in infants, and the illness is self-limiting.

\section{Physiopathology of Acute Viral Bronchiolitis}

Bronchial obstruction is the end point of various lower respiratory tract diseases with an allergic or infectious etiology. Inflammation, which is the result of many pathological processes, triggers capillary dilation and extravasation of plasma into the bronchial wall leading to edema. Goblet cells hyperplasia develops, with excessive mucus production, resulting in narrowing or occlusion of the smaller airways, with ventilation dysfunction. ${ }^{11,12} \mathrm{Re}$ peated episodes of bronchoconstriction may also lead to structural changes in the walls of the small airways, known as remodeling. ${ }^{13}$

\section{Treatments in Acute Viral Bronchiolitis}

Recommendations for management of acute viral bronchiolitis were published by the Subcommittee on Diagnosis and Management of Bronchiolitis in 2006. ${ }^{14}$

\section{Medications}

Currently there is no general agreement about medications. Bronchodilators, corticosteroids, and ribavirin are of little use. ${ }^{15,16}$ Antibiotics are indicated only in case of a bacterial complication. ${ }^{17}$ Nebulization of hypertonic saline is the treatment of choice for acute viral bronchiolitis, with reduction of the hospital stay and a better clinical score. ${ }^{18}$ Hypertonic saline has been validated and is reasonably safe. ${ }^{19}$ Adverse events, with coughing during nebulization, have been reported in $1 \%$ of cases, and bronchospasm in $0.3 \% .{ }^{20}$ Hypertonic saline increases the surface liquid by its osmotic action on the submucosal edema, improves mucociliary function, and facilitates CPT maneuvers. $^{21}$

\section{Chest Physical Therapy}

The aim of CPT is clearance of secretions and prevention of atelectasis and hyperinflation. The use of CPT in acute viral bronchiolitis has been debated for a long time, and the last Cochrane review concluded that CPT modalities (chest percussion, vibration in postural drainage po- sitions, and forced expiratory techniques) do not improve the course of the disease in hospitalized infants with acute viral bronchiolitis. ${ }^{22}$ As a result, CPT in acute viral bronchiolitis is no longer recommended, but recent publications cast doubt on that conclusion.

Various terms have been used to describe the CPT clearance procedures: chest physical therapy, CPT, bronchial clearance technique, conventional CPT, bronchial drainage or hygiene, airway clearance maneuvers or techniques, increased-exhalation technique (in French, accélération, augmentation du flux expiratoire). However, the functional and mechanical features of CPT have not been investigated in infants.

In Anglo-Saxon countries, in the 1960s, CPT in adults and children was called forced expiratory technique, and was associated with postural drainage and clapping; it was referred to as conventional CPT. ${ }^{23}$ It was mainly used to treat cystic fibrosis in adolescents and adults. Conventional CPT was applied to facilitate mucus evacuation through gravity. ${ }^{24-26}$ However, it should be remembered that mucociliary clearance is predominant in the dependent lung areas of semi-sitting infants, as in adults, being stimulated by regional ventilation. ${ }^{27-29}$ No wonder that conventional CPT gives poor results and is poorly tolerated, with side effects such as esophageal reflux, tachypnea, tachycardia, hypoxemia, rib fracture, and severe central nervous system complications, especially in newborns. ${ }^{30-34}$ The 2012 Cochrane review showed no significant benefit from conventional CPT on clinical score or hospital stay, and conventional CPT in acute viral bronchiolitis is no longer recommended. ${ }^{35-37}$

In France, increased-exhalation technique has been widely used in various ways since the 1970 s. $^{38-40} \mathrm{~A}$ robust thoraco-abdominal pressure is applied to mimic the forced expiratory technique. Controlled studies have demonstrated no benefit from increased-exhalation technique on hospital stay or cardiorespiratory parameters in severe acute viral bronchiolitis. ${ }^{41-43}$ In addition, side effects have been observed (vomiting, transient respiratory dysfunction, bouts of hypotonia), requiring interruption of the procedure. Rib fracture and mechanical drawbacks such as tracheal collapse leading to air and secretion trapping have also been observed. ${ }^{44-47}$

It should be stressed that conventional CPT and increased-exhalation technique have been extrapolated from the adult or adolescent to the infant respiratory system. But the latter has a greater density of submucosal glands, more acidic mucus with a greater viscosity, a more compliant chest wall, a greater tendency for airways collapse, and no collateral ventilation. Thus young infants tolerate respiratory loads poorly and are susceptible to fatigue because of the immature pattern of their muscle fibers. ${ }^{48,49}$ This explains why conventional CPT 
and increased-exhalation technique can be detrimental, and why these methods are no longer recommended.

Recently, a passive slow expiratory maneuver has been proposed and called prolonged slow expiration technique. ${ }^{50}$ The maneuver is preceded by hypertonic saline nebulization, and has shown to have significant effects on clinical symptoms in moderate bronchiolitis and a cumulative dayto-day improvement. ${ }^{51}$ Prolonged slow expiration technique is safe and well tolerated, as it is more attuned to the infant's mechanical respiratory system. Prolonged slow expiration technique avoids bronchial collapse with its flow interruption. The prolonged slow expiratory phase during prolonged slow expiration technique exhales a significant portion of the expiratory reserve volume. The reduction in lung volume is associated with the protective reflex of the airways, which restores lung volume by sigh breathing (Hering-Breuer deflation reflex). ${ }^{52}$ As secretions reach the proximal airways, provoked cough takes over.

Another recent randomized controlled trial using the prolonged slow expiration technique and increased-exhalation technique maneuvers during the same session, in hospitalized acute viral bronchiolitis infants, did not demonstrate a more rapid return to clinical stability. ${ }^{53}$ Yet in this study there was a lack of stratification of the initial clinical severity score, and CPT was not preceded by hypertonic saline nebulization. Nevertheless, the authors noted a significant decrease of the respiratory score. CPT may delay or prevent the need for mechanical ventilation and may result in fewer complications, but the study was unable to demonstrate such outcomes, as the study did not have sufficient power.

Also, the Gajdos et al study ${ }^{41}$ and the Rochat et al study ${ }^{53}$ have identified patient subgroups whose auscultation was improved by this treatment. This improvement would be due to the absence of atopic background.

Another study comparing $3 \mathrm{CPT}$ protocols in infants with acute viral bronchiolitis found clinical benefits for prolonged slow expiration technique and for conventional CPT, with longer benefits for prolonged slow expiration technique. ${ }^{54}$ At this point in time, a multicenter study would be needed to establish the usefulness of prolonged slow expiration technique preceded by hypertonic saline nebulization in moderate acute viral bronchiolitis.

\section{Summary}

CPT in acute viral bronchiolitis is mainly symptombased. Edema is the first target of treatment, and hypertonic saline should precede the CPT maneuvers (Figure). Further controlled studies based on physiopathology and grading of bronchial obstruction should better define the indications and contraindications for CPT in acute viral bronchiolitis.

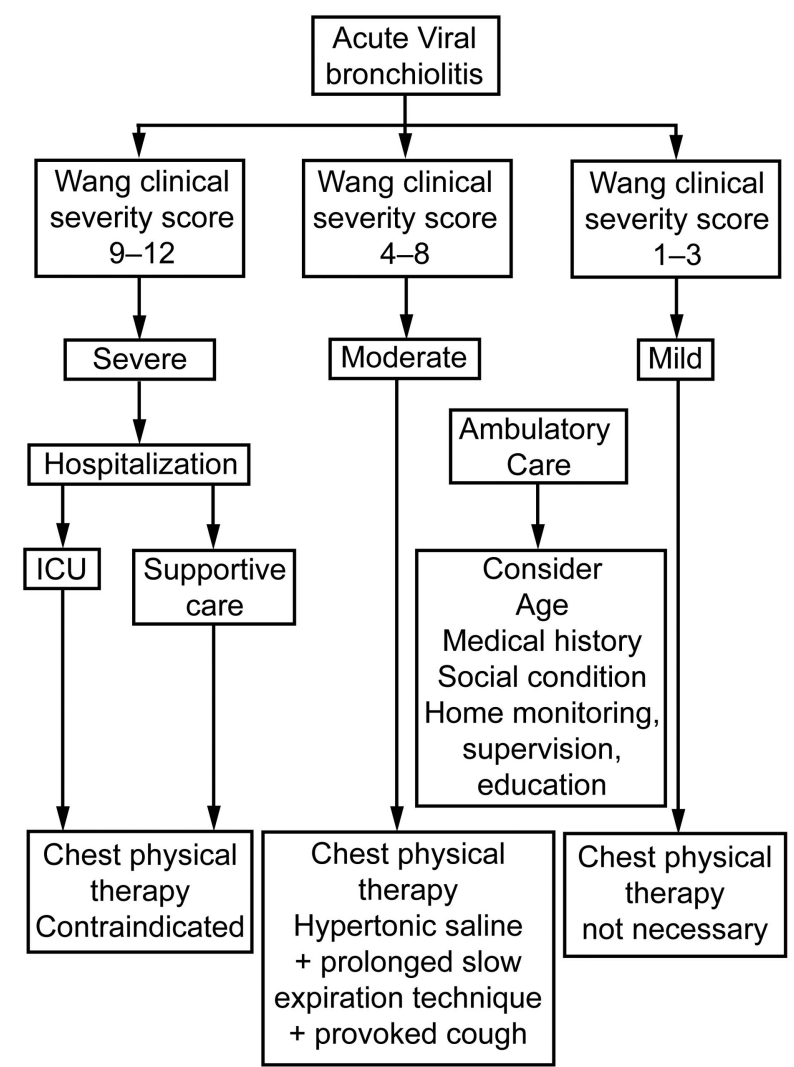

Figure. Algorithm for assessing indications and contraindications for chest physical therapy in acute viral bronchiolitis.

\section{ACKNOWLEDGMENTS}

We thank Henri C Labasse MD, Department of Neurosciences, Grand Hôpital de Charleroi, Charleroi, Belgium, for assistance with translation.

\section{REFERENCES}

1. Manoha C, Espinosa S, Aho SL, Huet F, Pothier P. Epidemiological and clinical features of hMPV, RSV and RVs infections in young children J Clin Virol 2007;38(3):221-226.

2. Wang EE, Milner RA, Navas L, Maj H. Observer agreement for respiratory signs and oximetry in infants hospitalized with lower respiratory infections. Am Rev Respir Dis 1992;145(1): 106-109.

3. Sarrel EM, Tal G, Witzling M, Someck E, Houri S, Cohen HA, Mandelberg A. Nebulized 3\% hypertonic saline solution treatment in ambulatory children with viral bronchiolitis decreases symptoms. Chest 2002;122(6):2015-2020.

4. Mandelberg A, Tal G, Witzling M, Someck E, Houri S, Balin A, Priel IE. Nebulized 3\% hypertonic saline solution treatment in hospitalized infants with viral bronchiolitis. Chest 2003;123(2):481-487.

5. Al-Ansani K, Sakran M, Davidson BL, Mahjoub H, Ibrahim K. Nebulised $5 \%$ or $3 \%$ hypertonic or $0.9 \%$ saline for treating acute bronchiolitis in infants. J Pediatr 2010;157(4):630-634.

6. Gajdos V, Beydon N, Bommenel N, Pellegrino B, de Pontual L, Bailleux S, et al. Inter-observer agreement between physicians, nurses, and respiratory therapists for respiratory clinical evaluation in bronchiolitis. Pediatr Pulmonol 2009;44(8):754-762. 


\section{Chest Physical Therapy in Acute Viral Bronchiolitis}

7. Davison C, Ventre KM, Luchetti M, Randolph AG. Efficacy of interventions for bronchiolitis in critically ill infants: a systematic review and meta-analysis. Pediatr Crit Care Med 2004;5(5):482489.

8. Javouhey E, Barats A, Richard N, Stamm D, Floret D. Non-invasive ventilation as primary ventilatory support for infants with severe bronchiolitis. Intensive Care Med 2008;34(9):1608-1614.

9. Wang EE, Law BJ, Stephens D; Pediatric Investigators Collaborative Network on Infections in Canada (PICNIC). Prospective study of risk factors and outcomes in patients hospitalized with respiratory syncytial viral lower respiratory tract infection. J Pediatr 1995;126(2): 212-219.

10. Donlan M, Fontela PS, Puligandla PS. Use of continuous positive airway pressure (CPAP) in acute viral bronchiolitis: a systematic review. Ped Pulmonol 2011;46(8):736-746.

11. Shaffer TH, Wolfson MR, Panitch HB. Airway structure, function and development in health and disease. Paediatr Anaesth 2004;14(1): 3-14.

12. Fahy JV, Dickey BF. Airway mucus function and dysfunction. N Engl J Med 2010;363(23):2233-2247.

13. Grainge CL, Lau LC, Ward JA, Dukay V, Lahiff G, Wilson S. Effect of bronchoconstriction on airway remodeling on asthma. N Engl J Med 2011;364(1):2006-2015.

14. American Academy of Pediatrics Subcommittee on Diagnosis and Management of Bronchiolitis. Diagnosis and management of bronchiolitis. Pediatrics 2006;118(4):1774-1793.

15. David M, Vanuxem CL, Loundou A, Bosdure, Auquier P, Dubus JC. [Assessment of the French Consensus Conference for Acute Viral Bronchiolitis on outpatient management: progress between 2003 and 2008]. Arch Pediatr 2010;17(2):125-131. Article in French.

16. Ralston S, Garber M, Narang S, Shen M, Pate B, Pope J, et al. Decreasing unnecessary utilization in acute bronchiolitis care: results from the value in inpatients pediatrics network. J Hosp Med 2012; $8(1): 25-30$.

17. Wainwright $\mathrm{C}$. Acute viral bronchiolitis in children: a very common condition with few therapeutic options. Paediatr Respir Rev 2010; 11(1):39-45.

18. Luo Z, Fu Z, Liu E, Xu X, Fu X, Peng D, et al. Nebulized hypertonic saline treatment in hospitalized children with moderate to severe viral bronchiolitis. Clin Microbiol Infect 2011;17(12):1829-1833.

19. Morawetz D, Cheah E, Barton R, Standish J, Connel TG. Is nebulized hypertonic saline useful as an adjunctive treatment for acute bronchiolitis in infants and children less than 24 months of age? J Paediatr Child Health 2011;47(12):922-926.

20. Ralston S, Hill V, Martinez M. Nebulized hypertonic saline without adjunctive bronchodilators for children with bronchiolitis. Pediatrics 2010;126(3):520-525.

21. Sauvaget F, David M, Bresson V, Retornaz K, Bosdure E, Dubus JC. Nebulized hypertonic saline and acute viral bronchiolitis in infants: current aspects. Arch Pediatr 2012;19(6):635-641.

22. Roqué i Figuls M, Giné-Garriga M, Granados Rugeles C, Perrotta C. Chest physiotherapy for acute bronchiolitis in paediatric patients between 0 and 24 months old. Cochrane Database Syst Rev 2012; (2):CD004873.

23. Thompson B, Thompson HT. Forced expiration exercises in asthma

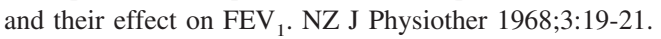

24. Frownfelter D. Chest physical therapy and pulmonary rehabilitation: an interdisciplinary approach. Chicago: Year Book Medical; 1987:678.

25. Oberwaldner B. Physiotherapy for airway clearance in paediatrics. Eur Respir J 2000;15(1):196-204.

26. Walsh BK, Hood K, Merrit G. Pediatric airway maintenance and clearance in the acute care setting: how to stay out of trouble. Respir Care 2011;56(9):1424-1444.
27. Postiaux G, Lens E, Alsteens G, Portelange P. Efficacité de l'Expiration Lente Totale Glotte Ouverte en décubitus Latéral (ELTGOL) sur la toilette en périphérie de l'arbre trachéobronchique. Ann Kinésithér 1990;17(3):87-99. Article in French.

28. Martins JA, Dornelas de Andrade A, Britto RR, Lara R, Parreira VF. Effect of slow expiration with glottis opened in lateral posture (ELTGOL) on mucus clearance in stable patients with chronic bronchitis. Respir Care 2012;57(3):420-426.

29. Pham TM, Yuill M, Dakin C, Schibler A. Regional ventilation distribution in the first months of life. Eur Respir J 2011;37(4): 919-924.

30. Wood BP. Infant ribs generalized periostal reaction resulting from vibrator chest physiotherapy. Radiology 1987;162(3):811-812.

31. Harding JE, Miles FK, Becroft DM. Chest physiotherapy may be associated with brain damage in extremely premature infants. J Pediatr 1998;132(3):440-444.

32. Beeby PJ, Henderson-Smart DJ, Lacey JL, Rieger I. Short and long term neurological outcomes following neonatal chest physiotherapy. J Paediatr Child Health 1998;34(1):60-62.

33. Coney S. Physiotherapy technique banned in Auckland. Lancet 1995; 145:510.

34. Buttom BM, Heine RG, Catto-Smith AG, Phelan PD, Olinsky A. Chest physiotherapy, gastro-oesophageal reflux, and arousal in infants with cystic fibrosis. Arch Dis Child 2004;89(5):435-439.

35. Schechter MS. Airway clearance applications in infants and children. Respir Care 2007;52(10):1382-1391.

36. De Boeck K, Vermeulen F, Vreys M. Airway clearance techniques to treat acute respiratory disorders in previously healthy children: where is the evidence? Eur J Pediatr 2008;167(6):607-612.

37. Behrendt CE, Decker MD, Burch DJ, Watson PH. International variation in the management of infants hospitalized with respiratory syncytial virus. International RSV Study Group. Eur J Pediatr 1998; 157(3):215-220.

38. Barthe J, Catalano G, Delaunay JP. Kinésithérapie respiratoire dans les bronchiolites. J Pédiatr Puériculture 1988;1:41-45. Article in French.

39. Groupe Francophone de Réanimation et d'Urgence Pédiatrique. Prise en charge des bronchiolites aigües du nourrisson. Propositions de la commission d'évaluation. Arch Pediatr Adolesc Med 1996;3:11911192. Article in French.

40. Proceedings 1ère conférence de consensus en kinésithérapie respiratoire. Lyon; 1994. Ann Kinésithér 1995;22:49-57. Article in French.

41. Gajdos V, Katsahian S, Beydon N, Abadie V, de Pontual L, Larrar S. Effectiveness of chest physiotherapy in infants hospitalized with acute bronchiolitis: a multicenter, randomized, controlled trial. PLoS Med 2010;7(9):e1000345.

42. Pupin MK, Ricetto AG, Ribeiro JD, Baracat EC. Comparison of the effects that two different respiratory physical therapy techniques have on cardiorespiratory parameters in infants with acute viral bronchiolitis. J Bras Pneumol 2009;35(9):860-867.

43. Sánchez Bayle M, Martín Martín R, Cano Fernández J, Martínez Sánchez G, Gómez Martín J, Yep Chullen G, García García MC. [Chest physiotherapy and bronchiolitis in the hospitalized infant. Double-blind clinical trial]. An Pediatr (Barc) 2012;77(1):5-11. Article in Spanish.

44. Chalumeau M, Foix-L'Helias L, Scheinmann P. Rib fractures after chest physiotherapy for bronchiolitis or pneumonia in infants. Pediatr Radiol 2002;32(9):644-647.

45. Berquier J, Lenoir M, Montagne JP. [Radiological quiz of the month: costal lump]. Arch Pediatr 2004;11(10):1212; 1230-1232. Article in French. 


\section{Chest Physical Therapy in Acute Viral Bronchiolitis}

46. Gorincour G, Dubus JC, Petit P, Bourliere-Najean B, Devred P. Rib periostal reaction: did you think about chest physical therapy? Arch Dis Child 2004;89(11):1078-1079.

47. Postiaux G, Lens E. De ladite "Accélération du Flux Expiratoire": où forced is . . Fast (Expiration Technique-FET)! Ann Kinésithér 1992;19(8):411-427. Article in French.

48. DiBlasi RM, Cheifetz IM. Neonatal and pediatric respiratory care: what does the future hold? Respir Care 2011;56(9):1466-1480.

49. Keens TG, Bryan C, Levison H, Ianuzzo CD. Developmental pattern of muscle fiber types in human ventilatory muscles. J Appl Physiol 1978;44(6):909-913.

50. Postiaux G. Des techniques expiratoires lentes pour l'épuration des voies aériennes distales. Rapport d'expertise. Proc Ière Conférence de Consensus sur la toilette bronchique Ann Kinésithér 1997;24(4): 166-177. Article in French.
51. Postiaux G, Louis J, Labasse HC, Patte C, Gerroldt J, Kotik AC, Lemuhot A. Effects of an alternative chest physiotherapy regimen protocol in infants with RSV bronchiolitis. Respir Care 2011;56(7): 989-994.

52. Lanza F, Wandalsen G, Dela Bianca AC, Cruz CL, Postiaux G, Solè D. Prolonged slow expiration technique in infants: effects on tidal volume, peak expiratory flow, and expiratory reserve volume. Respir Care 2011;56(12):1930-1935.

53. Rochat I, Leis P, Bouchardy M, Oberli C, Sourial H, Friedli-Burri M. Chest Physiotherapy using passive expiratory techniques does not reduce bronchiolitis severity: a randomised controlled trial. Eur J Pediatr 2012;171(3):457-462.

54. Gomes EL, Postiaux G, Medeiros DR, Monteiro KK, Sampaio LM, Costa D. Chest physical therapy in infant bronchiolitis: a randomized controlled trial. Rev Bras Fisioter 2012;16(3):241-247. 